\title{
Biocontrol of bacterial speck of tomato by aqueous extract of Tagetes erecta
}

\author{
Navodit Goel*, Kumari Anukrati, Prabir Kumar Paul \\ Amity Institute of Biotechnology, Amity University, Uttar Pradesh 48a, Knowledge Park III, \\ Greater Noida, Uttar Pradesh, 201308, India
}

\section{Vol. 57, No. 4: 361-369, 2017}

DOI: 10.1515/jppr-2017-0050

Received: February 6, 2017 Accepted: November 7, 2017

*Corresponding address: navoditgoel1985@gmail.com

\begin{abstract}
Biocontrol of plant diseases has emerged as an eco-friendly measure of plant protection and has experienced a lot of devotion in the last two decades. Biocontrol agents include application of microbial agents, their secretion products and natural extracts from different parts of several plants. The present study, therefore, aimed at evaluating the potency of aqueous extracts of Tagetes erecta L. (marigold) in controlling bacterial speck disease in tomato plants. The experimental design consisted of two groups of 50 plants each: group 1 - sprayed with sterile water (control); and group 2 - sprayed with marigold extract. Spraying was performed under aseptic conditions at the third node from the base of each plant. Challenge inoculation with the bacterial speck pathogen Pseudomonas syringae pv. tomato was performed to analyze the disease severity on the test plants. The parameters of study were analysis of alteration in the activity and gene expression of peroxidase (POX), phenyl ammonia lyase (PAL), and polyphenol oxidase (PPO), as well as isoform expression of POX and PPO. The results demonstrated strong inductive effects of the extract on the activity and genes of POX, PAL and PPO. De novo expression of POX and PPO isoforms following marigold extract treatment was also observed. The observations indicate that marigold extract could be a promising biopesticide.
\end{abstract}

Key words: biocontrol, PAL, POX, PPO, Pseudomonas syringae pv. tomato, Tagetes erecta

\section{Introduction}

Solanum lycopersicum (tomato) has been severely attacked by Pseudomonas syringae pv. tomato (Barone et al. 2008), the causal organism of bacterial speck. Prevalent chemical methods to control pathogens are environmentally unsafe (Luna et al. 2012). Therefore, there is an urgent need to develop alternate environmentally safe methods of disease control. Application of microbes (either individually or in combination, such as Plant Growth Promoting Rhizobacteria) (Yadav et al. 2015), their metabolites (Mitra et al. 2013) or natural plant extracts (Goel and Paul 2014) have been utilized for broad spectrum management of several biotic stresses in plants.

Foliar spraying of botanical extracts serves many biocontrol purposes. Several parts of Tagetes erecta L. (marigold) possess antimicrobial activities against a large array of pathogens (Xu et al. 2012). Pattnaik et al. (2012) demonstrated the control of several bacterial and fungal pathogens by spraying marigold extract on tomato leaves. Protection of eggplants from 16 pests under field conditions has been achieved by spraying marigold leaf extract on aerial parts of the plants by Azad et al. (2012).

Peroxidases (POXs) have long been known to be involved in defense responses in plants, mediating the redox reactions in plasma membranes, cell wall modifications (lignification and suberinization), auxin and ethylene metabolism, as well as in developmental processes (Goel et al. 2013). In tomato, more than 12 peroxidase isoenzymes have been described and 
seven of the coding genes have been mapped (El Mansouri et al. 1999). The POX genes have been shown to be induced in susceptible varieties of tomato plants under stress conditions (Mayda et al. 2000). They have also been found to be activated only upon compatible plant-pathogen interactions (Pilloff et al. 2002). The significant role of POXs in tomato defense against P. syringae pv. tomato has been demonstrated by Goel et al. (2013).

Phenyl ammonia lyase (PAL) is a critical defense enzyme ubiquitously expressed in plants, whose products are modified through phenylpropanoid metabolism to precursors of secondary metabolites, including lignin, flavonoid pigments, and phytoalexins, all of which play key roles in a range of plant-pathogen interactions (Morrison and Buxton 1993). PAL activity is often considered as an indicator of resistance since it accumulates more rapidly and reaches higher levels within host plants during resistance responses (Bhattacharyya and Ward 1988). Bhuvaneshwari et al. $(2012,2015)$ demonstrated an important role of PAL in providing resistance in tomato plants against bacterial speck.

Polyphenol oxidases (PPOs) are another group of enzymes which are expressed in plants under normal growth situations as well as stress conditions (Goel et al. 2014). Seven nuclear genes encoding PPOs have been reported in tomato (Newman et al. 1993). The over-expression of PPO in tomato led to a significant increase in resistance against $P$. syringae pv. tomato in compatible interactions, while antisense downregulation of a PPO gene resulted in enhanced disease susceptibility in the plant (Goel 2014). Salicylic acid foliar spray induced resistance against bacterial spot in tomato mediated by increased PPO activity (Ibrahim 2012).

The present study, therefore, aimed at investigating the potency of an aqueous extract of Tagetes erecta leaves in inducing defense genes of PAL, POX and PPO in tomato, eventually leading to control of the deadly bacterial speck disease in them.

\section{Materials and Methods}

\section{Raising of plants}

Surface sterilized and aseptically dried tomato seeds (Roopsi variety, Century seeds, New Delhi, India) were sown in sterilized soilrite in plastic trays. The plants were raised in a sterile culture room, under aseptic conditions and maintained at $25 \pm 11^{\circ} \mathrm{C}$ with a relative humidity of $70 \%$ and a photoperiod of $12 \mathrm{~h} \mathrm{~L}: \mathrm{D}$. Trays were watered daily with autoclaved distilled water and once a week with Hoagland's solution.

\section{Aqueous marigold leaf extract preparation}

Approximately $100 \mathrm{~g}$ of mature marigold leaves were surface sterilized with $0.9 \%$ sodium hypochlorite solution and macerated in $100 \mathrm{ml}$ sterile distilled water in a pre-chilled mortar and pestle under aseptic conditions. The extract obtained was filtered through 4-layered muslin cloth and the filtrate was centrifuged at $8,000 \times g$ at $4^{\circ} \mathrm{C}$ for $30 \mathrm{~min}$. The supernatant obtained was filtered through a $0.45 \mu \mathrm{m}$ membrane filter (to prevent any contamination) and used for spraying on to the host plants.

\section{In vitro antibacterial assay}

The marigold leaf extract was analyzed for in vitro antibacterial activity against Pseudomonas syringae pv. tomato by a standard agar well diffusion assay (Goel and Paul 2015). Highly virulent bacterial strains, isolated from infected tomato fruits, were utilized at $10^{8}$ colony forming units $(\mathrm{CFU}) \cdot \mathrm{ml}^{-1}$ concentration. The bacterial suspension was uniformly distributed $(0.1 \mathrm{ml}$ per Petri dish) using a spreader on Pseudomonas-specific King's B agar medium. Wells ( $5 \mathrm{~mm}$ ) were made in the agar plate with a sterile cork borer. Marigold extract $(0.1 \mathrm{ml})$ was poured into the respective wells and incubated at $25 \pm 1^{\circ} \mathrm{C}$ for $24 \mathrm{~h}$. The antibacterial activity of aqueous marigold leaf extract was expressed in terms of the mean of the diameter of the zone of inhibition (in $\mathrm{mm}$ ) produced. This test was carried out under aseptic laboratory conditions and repeated five times, two replicates each.

\section{Elicitation treatments}

Ten-week-old tomato plants were divided into two groups of 50 plants each:

1) group 1 - sprayed with sterile water (control);

2) group 2 - sprayed with marigold extract.

The spraying was performed under aseptic conditions at the third node from the base of each plant. Samples were collected for both treated (third nodal leaf) and untreated (distal leaves above the third node) leaves at $0,24,48$ and $72 \mathrm{~h}$ intervals. The samples were immediately stored at $-20^{\circ} \mathrm{C}$ and subsequently used for analysis of various parameters under study.

\section{Disease severity calculation}

The disease severity in challenge-inoculated plants was measured as the \% area of leaf infected according to the method described by Goel and Paul (2015). The untreated distal leaves of all the test plants were 
inoculated with pathogen seven days after the respective treatment. The severity of bacterial speck disease on them was calculated by counting the lesions of bacterial speck on leaves per plant. Disease severity was evaluated visually and scored using a disease index with a range of 0 to 3 ( 0 - a healthy-looking plant; 1 - 2-5 specks together or spread over each leaf; 2 - 6-10 specks; and 3 - more than 10 specks). Disease severity was evaluated using the following formula:

$$
\begin{gathered}
\text { Disease severity }[\%]= \\
=\frac{\text { Sum of rating }(0-\text { scale }) \times 100}{\text { Maximum possible score } \times \text { No. of leaves observed }}
\end{gathered}
$$

\section{Cytoplasmic enzyme extraction}

The cytoplasmic enzymes were extracted by the method described by Goel and Paul (2014). 300 mg of frozen leaf tissue was homogenized in $1.2 \mathrm{ml}$ of ice cold sodium-phosphate buffer $(0.1 \mathrm{M}, \mathrm{pH} 9.0)$ containing $10 \mathrm{mM} \beta$-mercaptoethanol, $1 \mathrm{mM}$ phenyl methyl sulfonyl fluoride (PMSF), 0.001\% Triton X-100, $1 \mathrm{mM}$ EDTA and $10 \%(\mathrm{w} / \mathrm{w})$ polyvinylpyrrolidone (PVP) at $4^{\circ} \mathrm{C}$. The homogenate was centrifuged at $10,000 \mathrm{rpm}$ for $20 \mathrm{~min}$ at $4^{\circ} \mathrm{C}$. The supernatant was used as crude enzyme extract for estimation of PAL, POX and PPO activities, and in-gel-activity-staining of POX and PPO isoforms. Each enzyme estimation assay had five replicates from five different samplings.

\section{Estimation of enzyme activities}

POX activity was measured according to the method of Goel and Paul (2014). The reaction mixture consisted of $0.245 \mathrm{ml}$ of sodium-phosphate buffer ( $1 \mathrm{M}$, $\mathrm{pH} 7.0), 0.25 \mathrm{ml}$ of guaiacol $(0.1 \mathrm{M}), 0.05 \mathrm{ml}$ hydrogen peroxide $\left(\mathrm{H}_{2} \mathrm{O}_{2}\right), 0.05 \mathrm{ml}$ of crude enzyme extract and $1.655 \mathrm{ml}$ of distilled water. The reaction mixture was incubated at $25 \pm 1^{\circ} \mathrm{C}$ for $5 \mathrm{~min}$ and the reaction was terminated by adding $0.5 \mathrm{ml} \mathrm{10 \%} \mathrm{(v/v)} \mathrm{sulphuric} \mathrm{acid.}$ Absorbance was recorded at $470 \mathrm{~nm}$ using UV-VIS spectrophotometer (Shimadzu, 1650, New Delhi, India). Enzyme activity was expressed as $\mathrm{mM} \cdot \mathrm{min}^{-1} \cdot \mathrm{g}^{-1}$ fresh weight.

For PAL activity, the reaction mixture contained $1 \mathrm{ml}$ of enzyme extract, $0.5 \mathrm{ml}$ of borate buffer $(\mathrm{pH} 8.7), 1.3 \mathrm{ml}$ of distilled water and $0.2 \mathrm{ml}$ of $1 \mathrm{M}$-phenylalanine. Changes in absorbance at $290 \mathrm{~nm}$ were observed at $30 \mathrm{~s}$ intervals for $10 \mathrm{~min}$ on a Biochrom UV-VIS spectrophotometer. Reaction mixture without substrate served as the blank (Bhuvaneshwari et al. 2012). One unit of enzyme activity was defined as the amount of enzyme required to produce $3.37 \mathrm{~nm}$ of cinnamic acid per hour. Results were expressed as units of activity $\cdot \mathrm{g}^{-1}$ fresh weight.

PPO activity was measured according to Goel and Paul (2015). The reaction mixture consisted of $0.5 \mathrm{ml}$ of sodium phosphate buffer (1 M, pH 9.0), $1.25 \mathrm{ml}$ of catechol $(0.2 \mathrm{M}), 0.05 \mathrm{ml}$ of enzyme extract and $0.2 \mathrm{ml}$ of distilled water. The reaction mixture was incubated at $25 \pm 1^{\circ} \mathrm{C}$ for $5 \mathrm{~min}$ and terminated by the ad-

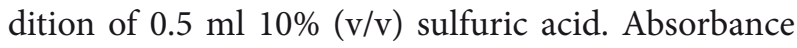
was recorded at $420 \mathrm{~nm}$ using a UV-VIS spectrophotometer (Shimadzu, 1650, New Delhi, India). Reaction mixture without enzyme extract served as the blank. Enzyme activity was expressed as units $\mathrm{g}^{-1} \cdot \mathrm{min}^{-1}$ fresh weight. One unit of enzyme activity was defined as the amount of enzyme required for a change in absorbance of 0.001 per minute.

\section{Native-Basic PAGE and in-gel-activity- -staining of POX and PPO isoforms}

$75 \mu \mathrm{g}$ proteins were loaded onto the native basic polyacrylamide gel for isoform analysis. The native gel consisted of $10 \%$ resolving gel and $4 \%$ stacking gel. Electrophoresis was carried out at $70 \mathrm{~mA} /$ gel for $3 \mathrm{~h}$ at $4^{\circ} \mathrm{C}$. After electrophoresis, the gels were stained for isoPOX by incubating in $0.1 \mathrm{M}$ sodium-phosphate buffer ( $\mathrm{pH} 7.0$ ) containing $10 \mathrm{mM}$ guaiacol and $0.75 \% \mathrm{H}_{2} \mathrm{O}_{2}$ (Goel et al. 2013). For PPO, the gel was equilibrated in $0.1 \% \mathrm{p}$-phenylene diamine followed by the addition of $50 \mathrm{mM}$ catechol in $0.1 \mathrm{M}$ sodium phosphate buffer (pH 7.0) (Goel and Paul 2015). The isoforms were distinguished by determining the Rf value of each band.

\section{Analysis of gene expression - RNA isolation}

RNA was isolated according to the method described by Bhuvanseshwari et al. (2015). Frozen leaf tissue $(100 \mathrm{mg}$ ) was homogenized using $1 \mathrm{ml}$ of trizol (Invitrogen, USA) extraction buffer, incubated for 2-3 min at room temperature. About $0.2 \mathrm{ml}$ of chloroform was added for each $1 \mathrm{ml}$ of initial trizol. It was shaken for $15 \mathrm{~s}$, and incubated for an additional 2-3 $\mathrm{min}$ at room temperature. The samples were centrifuged for $20 \mathrm{~min}$ at $4,000 \times g, 4^{\circ} \mathrm{C}$. The aqueous phase was removed and $550 \mu \mathrm{l}$ was transferred to an Eppendorf tube for each $1 \mathrm{ml}$ of trizol. Approximately $600 \mu \mathrm{l}$ is recoverable but for DNA contamination prevention, $550 \mu \mathrm{l}$ is recommended. About one volume of phenol : chloroform : : isoamyl alcohol $(25: 24: 1)$ was added to the aqueous phase, mixed well by vortexing and centrifuged for $\sim 10 \mathrm{~min}$ at $12,000 \times g, 4^{\circ} \mathrm{C}$. The aqueous phase was removed and transferred to a fresh tube containing an equal volume of chloroform, centrifuged under the same conditions and the aqueous phase was 
transferred to a new tube. About $0.25 \mathrm{ml}$ isopropanol and $0.25 \mathrm{ml}$ of $1.2 \mathrm{M} \mathrm{Na}$-citrate/0.8 M NaCl was added to each Eppendorf tube. The tubes were inverted for mixing and kept for 2-3 min. The tubes were centrifuged at $4^{\circ} \mathrm{C}, 12,000 \times g$ for $10 \mathrm{~min}$. The supernatant was removed and the pellet was washed with $1 \mathrm{ml}$ of filter sterilized $70 \%$ ethanol. The pellet was dried in a sterile hood. Complete drying of the pellets was avoided to prevent a decrease in the solubility of the RNA. The RNA sample was dissolved in $50 \mu \mathrm{l}$ of sterile DEPC treated water and stored at $-20^{\circ} \mathrm{C}$ until further use. Total RNA was quantified spectrophotometrically at an absorbance of $260 \mathrm{~nm}$ and an equal concentration of RNA for each sample was loaded.

The isolated RNA was converted to complementary DNA (cDNA) using cDNA kit (Chromous biotech Pvt. Ltd). The products of reverse transcription were used as templates for polymerase chain reaction (PCR) analysis using gene specific primers ( $\beta$-actin, $P A L$, $P O X$ and $P P O$ gene). The primers used were designed using Primer 3 software. PCR reactions were carried out in $10 \mu \mathrm{l}$ mixture containing $1 \mu \mathrm{l}$ of cDNA, $5 \mu \mathrm{l}$ of 2X master mix (Chromous biotech Pvt. Ltd), $1 \mu \mathrm{l}$ of $10 \mu \mathrm{M}$ forward primer, $1 \mu \mathrm{l}$ of $10 \mu \mathrm{M}$ reverse primer, $2 \mu \mathrm{l}$ of nuclease free water of each target and reference genes. The cycle numbers and annealing temperature were optimized to ensure that amplification of the reference gene and the gene of interest remained within the amplification range, thereby giving an accurate representation of transcript abundance. Amplification for $\beta$-actin, POX, PAL and PPO was carried out according to the following temperature profile: $94^{\circ} \mathrm{C}$ for $5 \mathrm{~min}$ for denaturation, followed by 30 cycles for $94^{\circ} \mathrm{C}$ for $1 \mathrm{~min}$, $54.8^{\circ} \mathrm{C}$ for $30 \mathrm{~s}, 72^{\circ} \mathrm{C}$ for $1 \mathrm{~min}$ with final elongation at $72^{\circ} \mathrm{C}$ for $5 \mathrm{~min}$. The differences in expression of genes (POX, PAL and PPO) due to neem fruit extract treated tomato plants were analysed in comparison with the control plants. $\beta$-actin gene expression was used as the standard. The primers used in this study as mentioned in Table 1 were synthesized by Chromous Biotech Pvt. Ltd, India. The PCR products were run on $2 \%$ agarose

Table 1. Primers for $\beta$-actin, $P A L, P O X$ and $P P O$

\begin{tabular}{ccc}
\hline Gene & Primers & $\begin{array}{c}\text { Amplicon } \\
\text { length }\end{array}$ \\
\hline 3-actin & F-5' TTGCCGCATGCCATTCT 3' & 73 \\
& R-5' CGGTGAGGATATTCATCAGGTT 3' & \\
\hline POX & F-5' GCTTTGTCAGGGGTTGTGAT 3' & 197 \\
& R-5'TGCATCTCTAGCAACCAACG 3' & \\
\hline PAL & F-5'TTCAAGGCTACTCTGGC 3' & 579 \\
\hline RPO & F-5'CAAGCCATTGTGGAGAT 3' & \\
\hline
\end{tabular}

(low EEO grade) gel supplemented with ethidium bromide (final concentration of $0.5 \mathrm{mg} \cdot \mathrm{ml}^{-1}$ ) for $2 \mathrm{~h}$ at $50 \mathrm{~V}$ in Tris-acetate EDTA buffer (Bhuvaneshwari et al. 2015). The thickness of the band indicating the level of expression of the respective gene was viewed in Gel Documentation System (Biorad Gel Doc. 2000 system).

\section{Statistical analysis of the data}

The data were statistically analyzed for analysis of variance (ANOVA) using the general linear model procedure and the least-square means test of the statistical software SAS (version 9.2 developed by SAS institute Inc., Cary, NC, USA). Multiple pairwise comparison tests using least-square means were performed for post-hoc comparisons after two way ANOVA with treatment and time as the two factors with replications. The corrections used for multiple comparisons were Tukey's honest significantly differences test (HSD) procedure. Data for disease severity were statistically analyzed by SPSS software for windows version 16 (SPSS Inc., Chicago, Illinois, USA) using univariate general linear model procedures and one-way ANOVA respectively followed by post-hoc comparisons using Tukey's HSD.

\section{Results}

\section{In vitro antibacterial assay and disease severity}

The antibacterial assay results demonstrated that the marigold extract was unable to inhibit the in vitro growth of $P$. syringae pv. tomato significantly $(\mathrm{p}=0.495)$. However, the disease severity in the test plants was reduced significantly $(\mathrm{p}=0.039)$ (Fig. 1). This proves that although the extract was not bactericidal in nature; it reduced bacterial populations

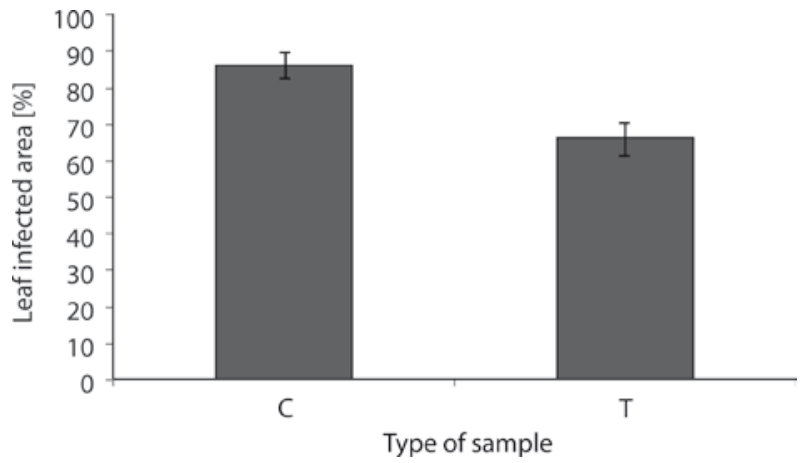

Fig. 1. Leaf infected area (\%) in the treated plants. $\mathrm{C}=$ control, $\mathrm{T}=$ test plants. The bars represent the average percentage disease severity $\pm \operatorname{SE}(n=5)$ 
on tomato, probably by inducing the defense enzymes which might have mediated the reduced disease severity.

\section{PAL, POX and PPO activities}

The Tagetes leaf extract could significantly induce the activities of PAL $(p=0.006)$, POX $(p=0.017)$ and PPO ( $\mathrm{p}=0.015)$ enzymes. Peroxidase activity was increased significantly $(\mathrm{p}<0.05)$ post elicitor application. The increment was observed at $24 \mathrm{~h}(\mathrm{p}=0.09)$ and $48 \mathrm{~h}(\mathrm{p}=0.003)$ in the treated and distal untreated leaves, respectively, which continued till $72 \mathrm{~h}$ (Fig. 2). Significant enhancement in the activity of PAL was also observed at $24 \mathrm{~h}$ of extract application in the test plants both at the site of treatment $(\mathrm{p}=0.02)$ as well as away from it $(\mathrm{p}=0.007)$; which continued up to the end of the sampling period (Fig. 3). Polyphenol oxidase was strongly induced by the extract at $48 \mathrm{~h}$ in the treated leaves ( $\mathrm{p}=0.006)$, however, its induction in the distal leaves was observed at $72 \mathrm{~h}(\mathrm{p}=0.035)($ Fig. 4$)$.

\section{POX and PPO isoforms}

A single POX isoform $(\mathrm{Rf}=0.38)$ was constitutively expressed in both the control and test samples. Two novel isoPOXs were observed in plants sprayed with marigold extract $(\mathrm{Rf}=0.33,0.41)$; in both the treated and untreated samples at $48 \mathrm{~h}$ (Fig. 5). Constitutive expression of two PPO isoforms $(\mathrm{Rf}=0.26,0.34)$ was observed in control and test plants. Application of marigold extract induced the expression of six more isoPPOs $(\mathrm{Rf}=0.20,0.30,0.32,0.36,0.38,0.40)$ both locally as well as systemically at $72 \mathrm{~h}$ (Fig. 6).

\section{Gene expression of PAL, POX and PPO}

The results demonstrate that the expression of $P O X$, $P A L$ and $P P O$ genes was significantly $(\mathrm{p}<0.05)$ induced by the marigold extract, whereas that of $\beta$-actin was not. The expression pattern of the aforesaid genes in control and test plants has been demonstrated in Figure 7.

\section{Discussion}

The present study focused on evaluating the inductive effects of aqueous extracts of T. erecta leaves on the activities and gene expression of POX, PAL and PPO, and isoforms of POX and PPO in tomato which would reduce the incidence of bacterial speck on the host plant. The results clearly demonstrate that marigold extract is potent enough to induce the expression of genes of the aforesaid enzymes. Since P. syringae pv. tomato was not inhibited by the application of the extract under culture conditions, the reduced disease severity could be attributed to the increased resistance of the plant against the pathogen, which was possibly mediated by the induction of defense enzymes such as POX, PAL and PPO by the extract. The induction of these as well as other unstudied defense enzymes could be critical to the sustenance of tomato plants against the everchallenging biotic and abiotic stresses.

Application of botanical extracts on different parts of plants has gained importance in the last few decades, as far as protection of plants from pests and pathogens in an eco-friendly manner is concerned. Extracts from different parts of marigold have been reported to possess

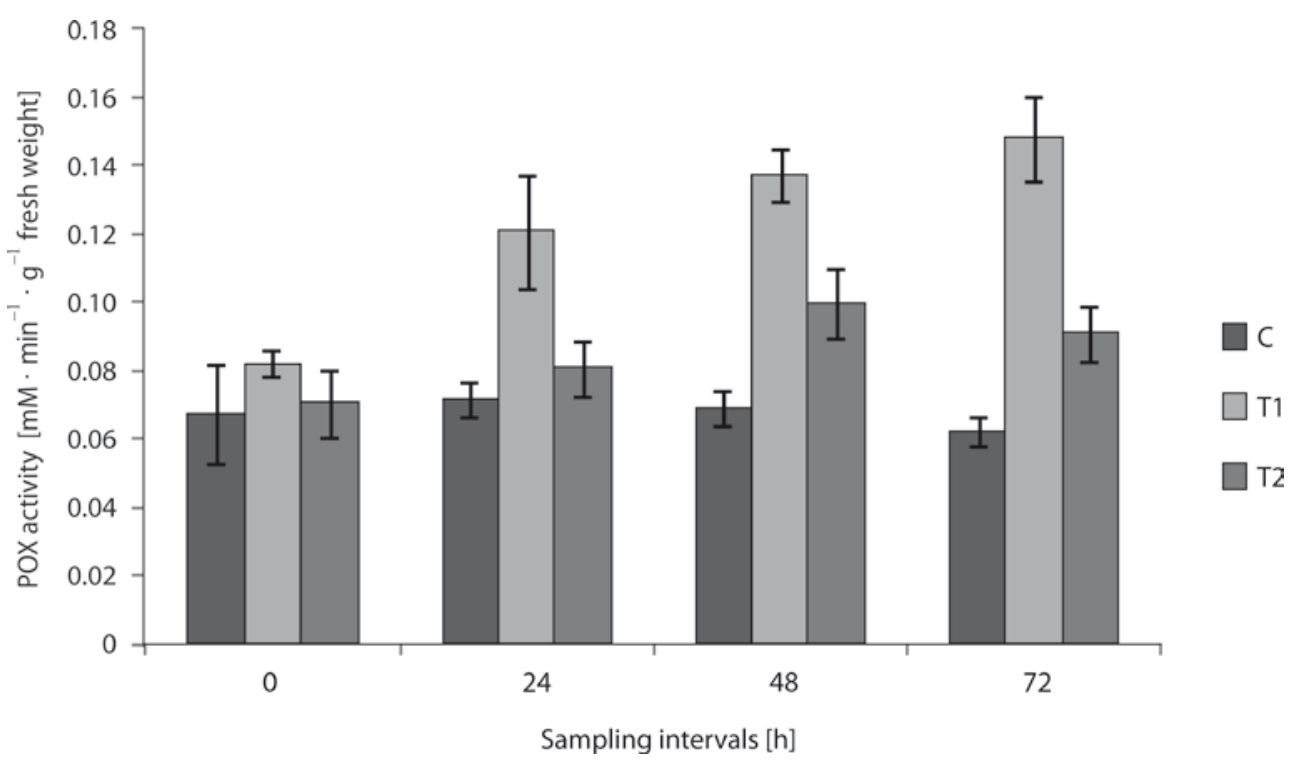

Fig. 2. Peroxidase (POX) activity in treated plants. $C=$ control, $T 1=$ treated leaves of test plants, $T 2=$ distal untreated leaves of test plants. The bars represent the average POX activity $\pm S E(n=5)$ 


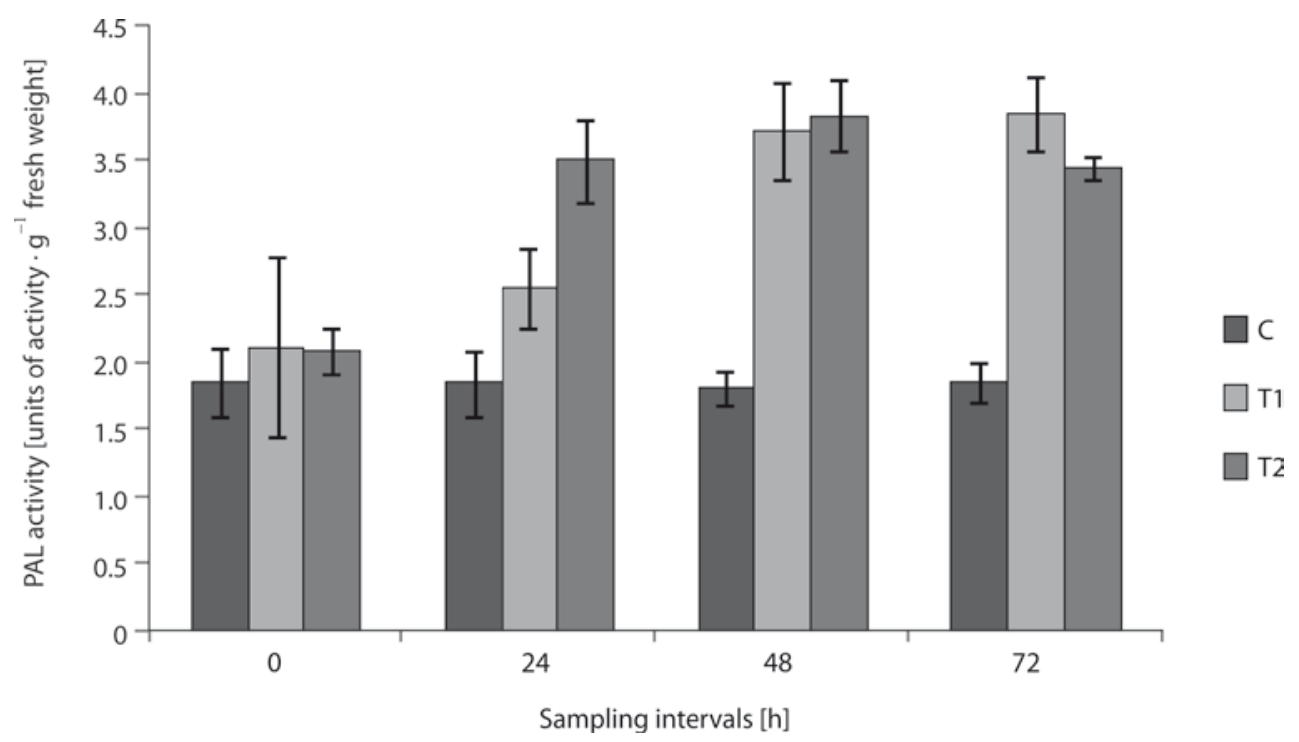

Fig. 3. Phenyl ammonia lyase (PAL) activity in treated plants. $C=$ control, $T 1=$ treated leaves of test plants, $\mathrm{T} 2=$ distal untreated leaves of test plants. The bars represent the average PAL activity $\pm \operatorname{SE}(n=5)$

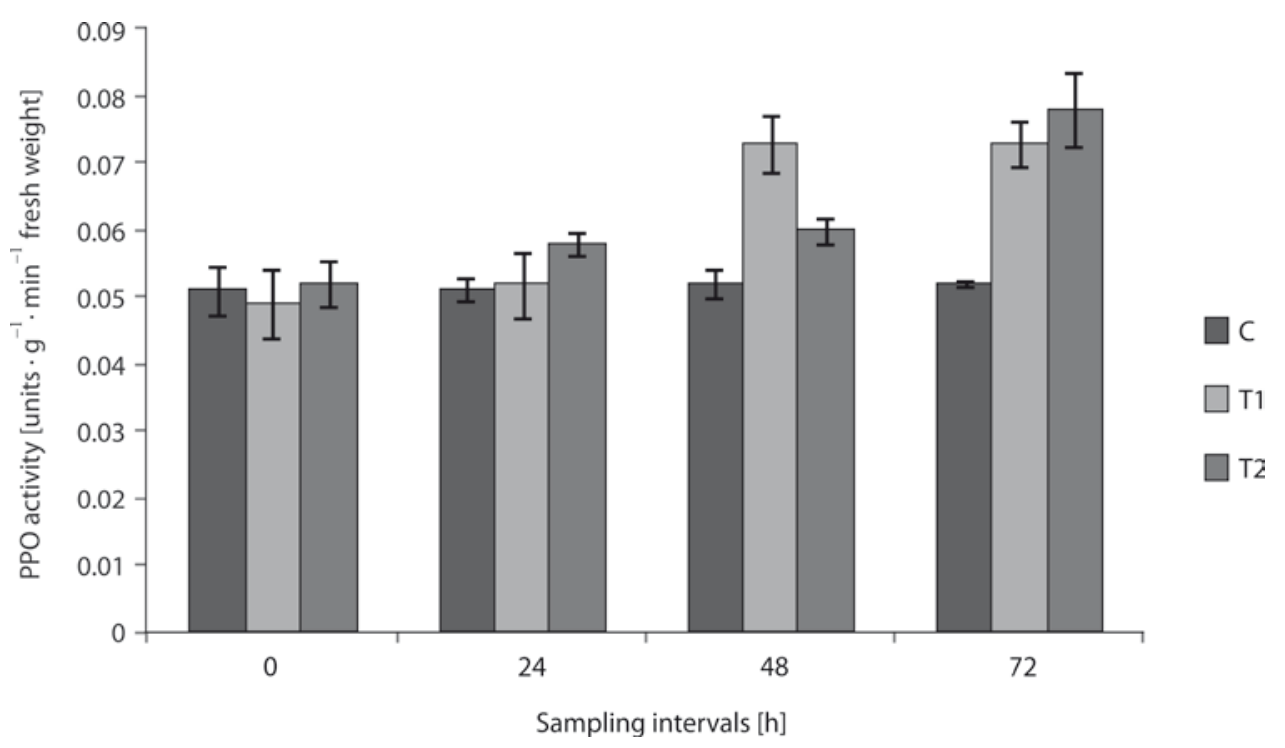

Fig. 4. Polyphenol oxidase (PPO) activity in treated plants. $C=$ control, $T 1=$ treated leaves of test plants, $T 2=$ distal untreated leaves of test plants. The bars represent the average PPO activity \pm SE $(n=5)$

antimicrobial as well as defense inducing properties (Koul et al. 2008; Xu et al. 2012; Javier and Brown 2013; Mahmoud et al. 2013). Weekly application of aqueous extracts of flowers, roots and leaves of Tagetes sp. was reported to control the populations of Meloidogyne incognita on tomato foliage (Dias-Arieira et al.2013).

The results of PAL activity and gene expression analysis clearly point out the inductive effect of the extract on it. The enhancement of PAL activity was observable within a day of application which persisted till the end of the sampling period, indicating the long term resistance provided by the defense protein. Implications of PAL have been found in synthesis of phenolic compoundsviathedefense-associated phenylpropanoid pathway (Raju et al. 2008). Application of Azadirachta indica leaf extract to barley plants could increase the PAL expression which led to rapid accumulation of antimicrobial phytoalexins, thus providing control of the leaf stripe pathogen Dreshlera graminea (Paul and Sharma 2002). Bhuvaneshwari et al. (2012) found a significant increase in PAL activity in tomato plants leading to the establishment of systemic acquired resistance in the host against $P$. syringae pv. tomato.

Peroxidase activity and expression of its isoforms and gene were substantially induced by the marigold extract during the present study. The appearance of 


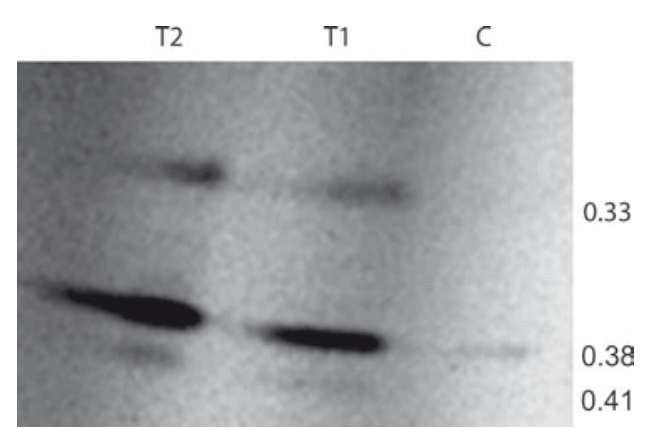

Fig. 5. In-gel-activity in gels stained for POX isoforms. C = control, $\mathrm{T} 1=$ treated leaves of test plants, $\mathrm{T} 2=$ distal untreated leaves of test plants. The numbers at right are the Rf values of the corresponding POX isoform

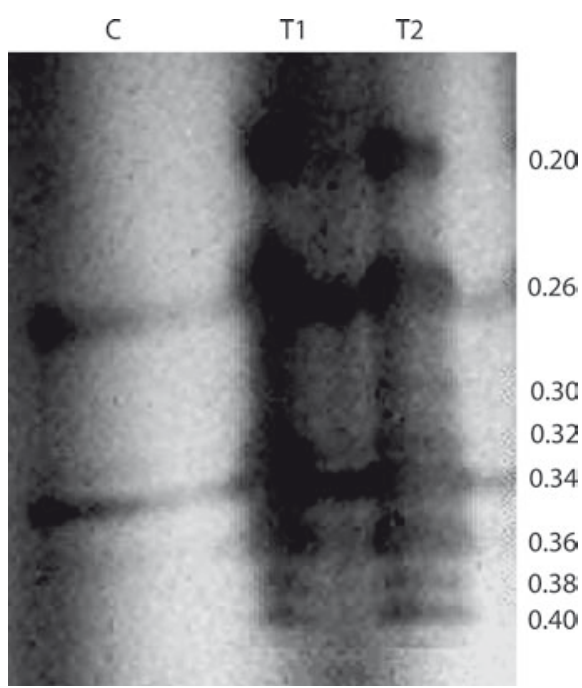

Fig. 6. In-gel-activity in gels stained for PPO isoforms. $C=$ control, $\mathrm{T} 1=$ treated leaves of test plants, $\mathrm{T} 2=$ distal untreated leaves of test plants. The numbers at right are the Rf values of the corresponding PPO isoform

additional isoPOXs after marigold extract application suggested that either the already expressed but inactive POX isoforms were activated or new ones were expressed post-treatment. Peroxidases have been implicated in several physiological processes during the induction of hypersensitive responses. They might have created a toxic environment inside the cell cytoplasm by the generation of reactive oxygen species (ROS) which probably inhibited the invading pathogen. POX-mediated formation of physical barriers in host cell walls by enhanced lignifications, polymerization of lignin and suberin and cross linking of other wall proteins to prevent the entry of the pathogen into the cell might also have increased resistance of tomato against P. syringae pv. tomato (Goel 2014). It has been suggested that expression of Ep5C (corresponding to POX CEVI16) in tomato upon inoculation with

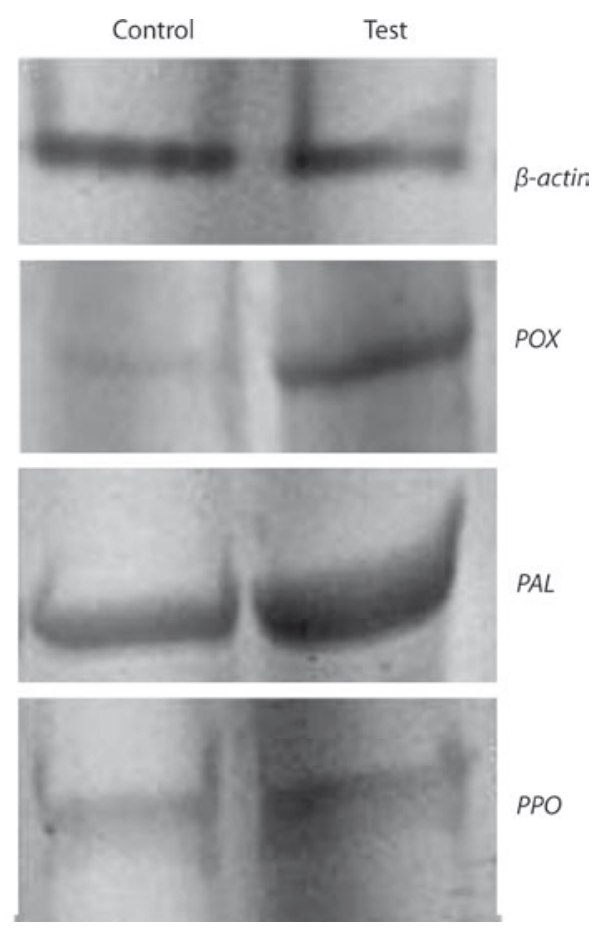

Fig. 7. Expression pattern of $\beta$-actin, $P A L, P O X$ and $P P O$ genes in control and treated plants

P. syringae pv. tomato might be necessary for modification of a cell surface molecular target that could be a component of a basal host defense complex (Coego et al. 2005). Ashry et al. (2011) demonstrated positive correlation of resistance in flax with the increase in POX activity, accompanied by production of microtoxic free oxygen radicals and $\mathrm{H}_{2} \mathrm{O}_{2}$ upon infection with powdery mildew pathogen, Odium lini Skoric. Goel et al. (2013) and Goel and Paul (2014) showed that POX has a significant role in controlling bacterial speck in tomato after $A$. indica extract application.

In the present study, the marigold extract had a positive effect on PPO activity, its isoform and also gene expression. Enhanced PPO expression could have promoted accelerated cell death of the cells surrounding the infection site, thus preventing the spread of pathogen. Also, cross linking of carbohydrates, glycoproteins and lignin in the cell walls along with production of ROS in the cytoplasm might have occurred, thereby reducing pathogen progress and multiplication on tomato leaves. It has been reported that quinones generated in PPO over-expressing tomato plants could hinder the ingress of the $P$. syringae pv. tomato ( $\mathrm{Li}$ and Steffens 2002). The PPO activity was observed to be higher in all the developmental stages of resistant genotypes of maize in comparison to the susceptible ones which were responsible for lignifications of the host cell walls (Purwar et al. 2012). The crucial role of PPO in implicating resistance in tomato plants of 
different varieties has been proposed previously (Goel et al. 2013; Goel and Paul 2015).

A significant inductive effect of $T$. erecta leaf extract on PAL, POX and PPO expression was the highlight of this study. Implications of using extracts from different parts of marigold as a potential biopesticide have not been exploited widely. In the present study, the authors have tried to inculcate the possibility of a natural plant extract in inducing resistance in an economically important crop like tomato. The results have been motivating enough for further research. Studies on the broad spectrum control of diseases by this extract would be of great interest in further research. Also, the compounds present in the extract, the effect of the extract on the cell wall proteome of the target plant and on the expression of several other defense associated pathogenesis-related proteins as well as the non-negative effect on normal host physiological processes need to be worked out to establish marigold extract as a biopesticide for biocontrol of P. syringae pv. tomato.

\section{Acknowledgements}

The authors sincerely thank Amity University, Noida for providing necessary infrastructural facilities to carry out the research work.

\section{References}

Ashry N.A., Mohamed H.I. 2014. Impact of secondary metabolites and related enzymes in flax resistance and/or susceptibility to powdery mildew. African Journal of Biotechnology 11 (5): 1073-1077.

Azad M.A.K., Yesmin M.N., Islam M.S. 2013. Effect of botanical extract on pest control in brinjal field. Journal of Environmental Science and Natural Resources 5 (2): 173-176.

Barone A., Chiusano M.L., Ercolano M.R., Giuliano G., Grandillo S., Frusciante L. 2008. Structural and functional genomics of tomato. International Journal of Plant Genomics: e820274. DOI: http://doi.org/10.1155/2008/820274.

Bhattacharyya M.K., Ward E.W.B. 1988. Phenylalanine ammonia lyase activity in soybean hypocotyls and leaves following infection with Phytophthora megasperma f.sp. glycinea. Canadian Journal of Botany 66 (1): 18-23. DOI: https://doi. org/10.1139/b88-003

Bhuvaneshwari V., Paul P.K. 2012. Transcriptional and translational regulation of defense enzymes induced by neem fruit extract in tomato. Archives of Phytopathology Plant Protection 45 (12): 1374-1385. DOI: http://dx.doi.org/10.1080/03 235408.2012.655931

Coego A., Ramirez V., Ellul P., Mayda E., Vera P. 2005. The $\mathrm{H}_{2} \mathrm{O}_{2}-$ -regulated Ep5C gene encodes a peroxidase required for bacterial speck susceptibility in tomato. The Plant Journal 42 (2): $283-293$. DOI: $10.1111 / j .1365-313 X .2005 .02372 . x$

Dias-Arieira C.R., de Melo Santana-Gomes S., Puerari H.H., Fontana L.F., Ribeiro L.M., Mattei D. 2013. Induced resistance in the nematodes control. African Journal of Agricultural Research 8 (20): 2312-2318.

El Mansouri I., Mercado J.A., Santiago-Dómenech N., PliegoAlfaro F., Valpuesta V., Quesada M.A. 1999. Biochemical and phenotypical characterization of transgenic tomato plants overexpressing a basic peroxidase. Physiologia Plantarum 106 (4): 355-362. DOI: 10.1034/j.1399-3054 $.1999 .106401 . x$

Goel N. 2014. Study of expression of genes involved in induction of systemic acquired resistance in Lycopersicum esculentum by fruit extracts of Azadirachta indica against Pseudomonas syringae pv. tomato. Ph.D. thesis, Amity Institute of Biotechnology, Amity University, Noida, Uttar Pradesh, India, $196 \mathrm{pp}$.

Goel N., Paul P.K. 2014. Induction of systemic resistance in tomato by fruit extracts of Azadirachta indica. Reviews of Literature 2 (2): 1-27.

Goel N., Paul P.K. 2015. Plant age affects elicitation of polyphenol oxidase activity by neem extract in Solanum lycopersicum against Pseudomonas syringae pv. tomato. Israel Journal of Plant Sciences 62 (4): 283-293.

Goel N., Sahi A.N., Paul P.K. 2013. Age as a factor in induction of systemic acquired resistance in tomato against bacterial speck by aqueous fruit extracts of Azadirachta indica. Archives of Phytopathology Plant Protection 46 (14): 1696-1706. DOI: http://dx.doi.org/10.1080/03235408.2013.774529

Goel N., Sahi A.N., Paul P.K. 2014. Stage-specific induction of systemic acquired resistance by fruit extracts of Azadirachta indica. Archives of Phytopathology Plant Protection 47 (4): 477-489. DOI: http://dx.doi.org/10.1080/07929978.2015.10 35606

Ibrahim Y.E. 2012. Activities of antioxidants enzymes in salicylic acid treated tomato against Xanthomonas vesicatoria. African Journal of Microbiological Research 6 (27): 5678-5682. DOI: 10.5897/AJMR12.733

Javier P.A., Brown M.B. 2007. Bio-fertilizers and bio-pesticides research and development at UPLB. Food and fertilizer technology center (FFTC). Available on: http://www.fftc. agnet.org/library.php? func $=$ viewandstyle $=$ typeandid $=2011$ 0712070234. [Accessed: January 25, 2017]

Koul O., Walia S., Dhaliwal G.S. 2008. Essential oils as green pesticides: potential and constraints. Biopesticides International 4 (1): 63-84.

Li L., Steffens J.C. 2000. Overexpression of polyphenol oxidase in transgenic tomato plants results in enhanced bacterial disease resistance. Planta 215 (2): 239-247. DOI: 10.1007/ s00425-002-0750-4

Luna E., Bruce T.J.A., Roberts M.R., Flors V., Ton J. 2012. Nextgeneration systemic acquired resistance. Plant Physiology 158 (2): 844-853. DOI: 10.1104/pp.111.187468.

Mahmoud G.I. 2013. Biological effects, antioxidant and anticancer activities of marigold and basil essential oils. Journal of Medicinal Plants Research 7 (10): 561-572.

Mayda E., Mauch-Mani B., Vera P. 2000. Arabidopsis dth 9 mutation identifies a gene involved in regulating disease susceptibility without affecting salicylic acid-dependent responses. Plant Cell 12 (11): 2119-2128. DOI: 10.1105/ tpc.12.11.2119

Mitra J., Bhuvaneshwari V., Paul P.K. 2013. Broad spectrum management of plant diseases by phylloplane microfungal metabolites. Archives of Phytopathology Plant Protection 46 (16): 1993-2001. DOI: http://dx.doi.org/10.1080/03235 408.2013.782648

Morrison T.A., Buxton D.R. 1999. Activity of phenylalanine ammonia-lyase, tyrosine ammonia-lyase, and cinnamyl alcohol dehydrogenase in the maize stalk. Crop Science 33: 1264-1268.

Newman S.M., Eannetta N.T., Yu H., Prince J.P., de Vicente M.C., Tanksley S.D., Steffens J.C. 1993. Organisation of the tomato polyphenol oxidase gene family. Plant Molecular Biology 21 (6): 1035-1051.

Pattnaik M.M., Kar M., Sahu R.K. 2012. Bioefficacy of some plant extracts on growth parameters and control of diseases in Lycopersicum esculentum. Asian Journal of Plant Science Research 2 (2): 129-142. 
Paul P.K., Sharma P.D. 2002. Azadirachta indica leaf extract induces resistance in barley against leaf stripe disease. Physiology and Molecular Plant Pathology 61 (1): 3-13. DOI: https://doi.org/10.1006/pmpp.2002.0412

Pilloff R.K., Devadas S.K., Enyedi A., Raina R. 2002. The Arabidopsis gain-of-function mutant dll1 spontaneously develops lesions mimicking cell death associated with disease. The Plant Journal 30 (1): 61-70.

Purwar S., Gupta S.M., Kumar A. 2012. Enzymes of phenylpropanoid metabolism involved in strengthening the structural barrier for providing genotype and stage dependent resistance to karnal bunt in wheat. American Journal of Plant Sciences 3 (2): 261-267. DOI: 10.4236/ajps.2012.32031
Raju S., Jayalakshmi S.K., Sreeramulu K. 2008. Comparative study on the induction of defense related enzymes in two different cultivars of chickpea (Cicer arietinum $\mathrm{L}$ ) genotypes by salicylic acid, spermine and Fusarium oxysporum f. sp. ciceri. Australian Journal of Crop Science 2 (3): 121-140.

Yadav A., Gaur I., Goel N., Mitra M., Saleem B., Goswami S., Paul P.K., Upadhyaya K.C. 2015. Rhizospheric microbes are excellent plant growth promoters. Indian Journal of Natural Sciences 5 (30): 6584-6595.

Xu L.W., Juan C.H.E.N., Qi H.Y., Shi Y.P. 2012. Phytochemicals and their biological activities of plants in Tagetes L. Chinese Herbal Medicines 4 (2): 103-117. DOI: https://doi. org/10.3969/j.issn.1674-6384.2012.02.004 